\title{
Konsep taman edukasi berbasis aktivitas pelajar di sekolah dasar Islam terpadu Sholahuddin Bogor
}

\author{
Balqis Feparima Fasa ${ }^{{ }^{*}}$, Indung Sitti Fatimah ${ }^{1}$
}

1. Departemen Arsitektur Lanskap, Institut Pertanian Bogor, Indonesia

*E-mail: narfiko@gmail.com

\begin{abstract}
Education Garden Design Based on Students' activity in Advanced Moslem Elementary Sholahuddin Bogor. This research has purpose to detect landscape condition and usage in the specific school environment as a study that influence because of the user activity. There is a main idea to discuss, it is to create a suitable landscape that capable of accomodating the students activity that can affected the learning process so the student will be avoided by unnecessary stress caused by the long duration spent at school based on Islamic garden concept. Several methods will be used in this study, they are field survey, some of which are analysis, syntesis, and desigining methods. Field survey will be used to get primary data and acknowledge the student's activities and needs. This research is expected to be a recommendation design planning to create a better use for the school landscape that would be suitable and cope with the student's needs.
\end{abstract}

Keywords: education, Islamic garden, landscape design, school, school landscape

\section{Pendahuluan}

Sekolah adalah bangunan atau lembaga untuk belajar mengajar serta tempat menerima dan memberi pelajaran ataupun usaha menuntut kepandaian menurut Kamus Besar Bahasa Indonesia tahun 2010. Sekolah pada dasarnya merupakan lembaga pendidikan yang membantu membentuk karakter anak didik dengan melibatkan semua komponen pada sekolah, yaitu isi kurikulum, proses pembelajaran dan penilaian, kualitas hubungan, penanganan atau pengelolaan mata pelajaran, pengelolaan sekolah, pelaksanaan aktivitas, pemberdayaan sarana prasarana, serta dengan berinteraksi antara seluruh warga dan lingkungan sekolah (Widiastuti 2013).

Sekolah masa ini banyak terletak di kawasan perkotaan, dimana lingkungan dipadati oleh perumahan dan perkantoran sehingga siswa menjadi jarang berinteraksi dengan alam terbuka. Kurangnya interaksi dengan lingkungan hijau berdampak pada tekanan psikologis yang dialami oleh siswa-siswa tersebut. Interaksi dengan lingkungan alami juga diperlukan oleh anak untuk dapat berkembang di samping kegiatan akademis. Anak-anak yang dapat melihat dan menjalin kontak dengan alam mempunyai skor yang lebih tinggi dalam tes konsentrasi dan disiplin diri. Semakin hijau lingkungannya, semakin baik pula skornya (Faber Taylor et al. 2002).

Pada hakikatnya, meningkatkan kualitas lingkungan sekolah dapat memberi pengaruh baik terhadap semangat belajar siswa. Lanskap alami mampu membantu siswa pulih dari stres yang diakibatkan tekanan dari proses belajar (Venkatesha 2014). Matsuoka (2008) menyatakan dalam penelitiannya yang melibatkan 101 sekolah menengah atas di Michigan, pengaruh lanskap alami di lingkungan sekolah yang dapat dilihat siswa melalui jendela kelas mampu memberikan pengaruh baik terhadap peningkatan performa akademi siswa.

Sekolah Islam Terpadu Sholahuddin merupakan sekolah yang terletak di kawasan perkotaan padat penduduk di Kota Bogor. Sekolah Islam Terpadu Sholahuddin berlokasi di sebelah jalan raya Pasir Kuda, pertigaan yang merupakan salah satu titik macet utama Kota Bogor. Mengacu pada pendapat Nelson \& Porter tahun 1966, pembangunan kawasan sekolah di kawasan sibuk kurang berpengaruh baik pada sekolah. Kondisi ini dikhawatirkan menyebabkan kurang kondusifnya lingkungan pembelajaran Sekolah Islam Terpadu Sholahuddin, sehingga dibutuhkan suatu lingkungan yang dapat mendukung kegiatan belajar mengajar di sekolah untuk dapat meningkatkan performa akademi dengan meningkatkan pemanfaatan terhadap kualitas visual dan fungsionalnya sehingga tujuan dari kegiatan pembelajaran dapat dicapai. 


\section{Metode}

\subsection{Lokasi dan waktu studi}

Kota Bogor adalah sebuah kota di Provinsi Jawa Barat, Indonesia. Kota Bogor terletak pada $59 \mathrm{~km}$ sebelah selatan Provinsi DKI Jakarta, dan wilayahnya berada di tengah-tengah wilayah Kabupaten Bogor. Lokasi penelitian terletak di salah satu kelurahan di Kota Bogor, yaitu kelurahan Ciomas. Kondisi iklim pada tapak berdasarkan data dari Badan Lingkungan Hidup memiliki suhu udara rata-rata sebesar $26^{\circ} \mathrm{C}$, dengan suhu tertinggi $34,4^{\circ} \mathrm{C}$ dan suhu terendah $21,8^{\circ} \mathrm{C}$, serta kelembaban udara rata-rata $70 \%$. Penelitian ini akan diadakan di Sekolah Islam Terpadu Sholahuddin dimana pengadaan gedung sekolah baru tengah dilaksanakan. Fasilitas Sekolah Dasar akan dibangun di lahan seluas $3000 \mathrm{~m}^{2}$.

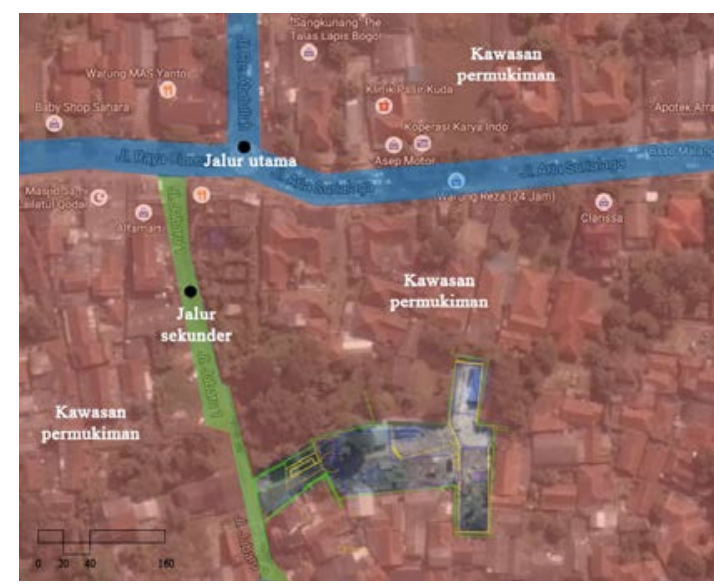

Gambar 1 Lokasi penelitian

Sumber: www.googlemaps.com

\subsection{Metode Penelitian}

Metode yang digunakan selama kegiatan penelitian Desain Taman Edukasi di Sekolah Islam Terpadu Sholahudin ini melalui beberapa kegiatan, diantaranya:

1) Inventarisasi

Inventarisasi merupakan kegiatan pengumpulan data yang dilakukan langsung pada tapak. Pengamatan langsung pada tapak dilakukan untuk memperoleh data fisik dan biofisik yang terdapat di dalam tapak seperti vegetasi dan satwa, topografi dan kemiringan, tanah dan hidrologi, fasilitas dan utilitas, aksesibilitas dan sirkulasi, serta visiual. Kegiatan ini dilakukan pada beberapa waktu yang berbeda, seperti pagi, siang, sore hari.

2) Analisis dan Sintesis

Kegiatan analisis dilakukan dengan metode pembahasan hasil dari kondisi umum dan menghasilkan block plan. Tahapan ini membutuhkan pendekatan dalam tiga aspek yaitu aspek biofisik, sosial, dan ekologi.

3) Desain

Proses ini merupakan tahapan dimana ukuran detail, bentuk, material, dan sistem konstruksi ditetapkan. Pada Desain Taman Edukasi ini, dengan menggunakan data sintesis berupa block plan yang diperoleh setelah melalui proses analisis, block plan tersebut kemudian akan digunakan dalam perencanaan dan perancangan Desain Taman Edukasi. Hasil dari kegiatan mendesain berupa siteplan yang dilengkapi dengan gambar potongan tampak dan detil penjelasannya.

\section{Hasil dan Pembahasan}

\subsection{Kondisi Umum}

Sekolah Islam Terpadu Sholahuddin terletak di Jalan Jabaru I, Kelurahan Ciomas, Kota Bogor. Lokasi sekolah terletak di tengah kawasan padat perkotaan. Akses utama menuju Sekolah Islam Terpadu Sholahuddin terdiri dari satu pintu gerbang utama yang menghadap jalan Jabaru I. Sirkulasi pada tapak merupakan jalan lurus menuju gerbang utama sekolah. Kemudian di dalam sekolah terdapat sirkulasi sekunder yang bebas bagi pengguna dikarenakan belum dibangunnya gedung sekolah dua, sehingga di depan gedung sekolah satu masih tampak seperti lapangan kosong karena tidak adanya perkerasan khusus 
untuk mengarahkan pengguna. Lahan Sekolah Dasar Islam Terpadu Sholahuddin relatif datar dengan jenis tanah latosol. Pada Sekolah Islam Terpadu Sholahuddin terdapat beberapa jenis vegetasi eksisting dengan tanaman yang beragam mulai dari tanaman penutup tanah, semak, hingga pohon. Beberapa contoh tanaman penutup tanah seperti rumput gajah (Axonopus compressus). Tanaman semak yang terdapat pada tapak seperti teh-tehan sementara tanaman pohon terdapat pohon kenari (Canarium indicum), pohon petai cina (Laucaena leucocephala), pohon melinjo (Gnetum gnemon), pohon pisang (Musa sp), pohon jambu air (Syzygium aqueum), dan pohon trembesi (Samanea saman).

Sekolah Islam Terpadu Sholahuddin memiliki beberapa fasilitas dan utilitas seperti sekolah pada umumnya. Fasilitas yang tersedia pada tapak antara lain area parkir, welcome area, gedung sekolah, lapangan olahraga, serta fasilitas seperti tempat sampah, toilet, dan vegetasi. Sekolah ini terdiri dari siswa kelas satu dan kelas dua dalam tingkat pendidikan dasar.

Siswa kelas satu terdiri dari 60 siswa, dan siswa kelas dua terdiri dari 58 siswa. Staf pengajar dan administrasi di sekolah Islam Terpadu Sholahuddin terdiri dari 20 orang. Hari belajar dimulai pada hari senin sampai hari jumat dalam satu minggu. Kegiatan pembelajaran dimulai pukul $07.30 \mathrm{WIB}$. Terdapat waktu istirahat pada pukul 09.30 WIB selama 30 menit sampai dengan pukul 10.00 WIB, dilanjutkan dengan kegiatan belajar kembali. Setelah itu terdapat waktu istirahat kedua yaitu pada pukul 12.00 WIB selama 45 menit sampai dengan pukul 12.45 WIB, dilanjutkan kembali dengan kegiatan pembelajaran. Kegiatan belajar mengajar berakhir pada pukul 14.00 WIB bagi siswa. Berdasarkan hasil inventarisasi, diperoleh keterangan bahwa siswa menghabiskan banyak waktu di lingkungan sekolah dengan berada di dalam ruang kelas. Peta inventarisasi dapat dilihat pada gambar 2.

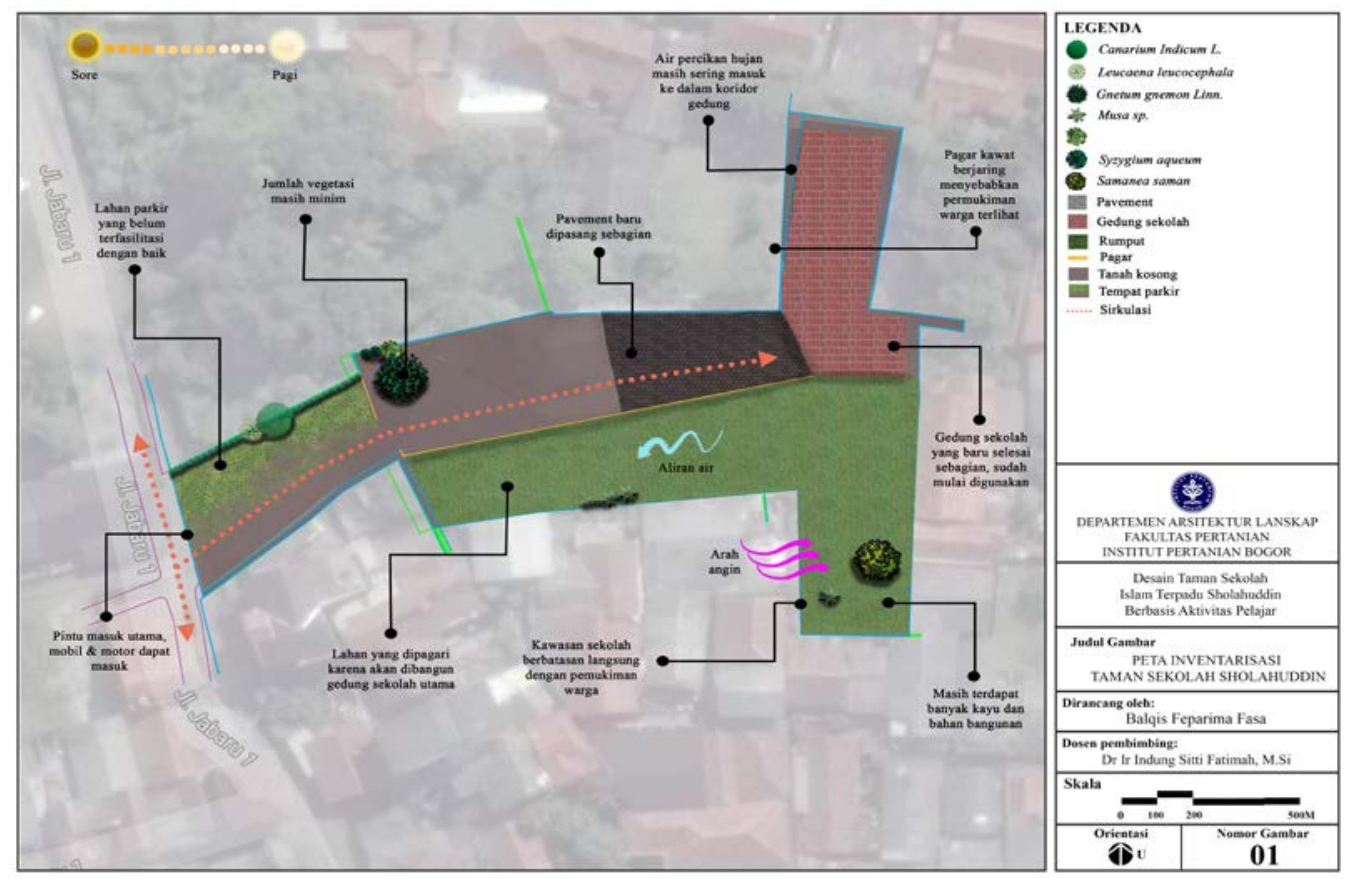

Gambar 2 peta inventarisasi

3.2

3.2.1 Lokasi dan Batas Tapak

Luas lahan Sekolah Dasar Islam Terpadu Sholahuddin yaitu $3000 \mathrm{~m}^{2}$ dengan jumlah siswa sebanyak 118 orang. Berdasarkan standar sarana \& prasarana SD/MI dalam peraturan pemerintah no. 24 tahun 2007, luas lahan ini tidak menjadi kendala bagi SDIT Sholahuddin. Peraturan Pemerintah tersebut menyatakan bahwa untuk SD/MI yang memiliki 15 sampai dengan 28 peserta didik per rombongan belajar, lahan dibutuhkan setidaknya sebesar $1460 \mathrm{~m}^{2}$ sebab gedung SDIT Sholahuddin terdiri dari tiga lantai. Sehingga luas sekolah masih sesuai dengan standar luas lahan sekolah berdasarkan peraturan pemerintah.

\subsubsection{Aksesibilitas dan Sirkulasi}

Pintu masuk utama ke dalam tapak harus jelas dan mudah ditemukan. Nama sekolah juga harus dipasang di tempat yang terlihat jelas dan dekat dengan pintu utama sekolah. Akses utama menuju sekolah terdiri dari satu pintu gerbang utama yang menghadap jalan Jabaru I. Jalan tersebut terbilang kecil karena tidak dapat dilewati oleh dua kendaraan beroda empat dalam waktu bersamaan. Hal ini menjadi hambatan 
bagi pengguna. Sirkulasi yang bebas terdapat di dalam tapak, namun belum ada perkerasan khusus untuk mengarahkan pengguna.

3.2.3 IKlim dan Suhu

Kondisi iklim pada tapak berdasarkan data dari Badan Lingkungan Hidup memiliki suhu udara ratarata sebesar $26^{\circ} \mathrm{C}$, dengan suhu tertinggi $34,4^{\circ} \mathrm{C}$ dan suhu terendah $21,8^{\circ} \mathrm{C}$, serta kelembaban udara ratarata $70 \%$.

3.2.4 Topografi

Topografi pada tapak yang datar merupakan potensi di lahan sekolah. Tidak perlu dilakukan proses cut dan fill untuk pembangunan karena bentuk lahan sudah datar. Penggunaan leveling dalam skala kecil dilakukan hanya untuk membedakan antara perkerasan dengan tanah serta antara satu area dengan area lain.

3.2.5 Jenis Tanah dan Hidrologi

Pada kawasan Sekolah Islam Terpadu Sholahuddin, tanah asli pada kawasan tersebut adalah tanah latosol. Namun dikarenakan pembangunan gedung sekolah membutuhkan kondisi tanah yang rata, maka tanah asli pada kawasan sekolah telah dimodifikasi dengan penambahan tanah latosol pada permukaannya.

3.2.6 Vegetasi

Vegetasi eksisting terdiri atas tanaman yang beragam mulai dari tanaman penutup tanah, semak, hingga pohon. Tanaman penutup tanah pada tapak adalah rumput gajah. Tanaman semaknya yaitu tehtehan, dan tanaman pohon terdapat pohon kenari, pohon petai cina, pohon melinjo, pohon pisang, pohon jambu air, dan pohon trembesi. Kondisi pohon pada tapak tidak tampak begitu baik, hal ini terlihat dari bentuk tajuk yang tidak penuh, dan pohon petai cina di bagian pintu masuk kawasan sekolah batangnya miring sehingga bisa membahayakan pengguna. Penambahan jumlah vegetasi akan dilakukan, baik itu berupa naungan maupun vegetasi estetika untuk meningkatkan kenyaman, memberi manfaat edukasi, serta menambah nilai estetik pada sekolah.

3.2.7 Visual

Sekolah Islam Terpadu Sholahuddin memiliki beberapa potensi good view pada bagian depan gedung sekolah yang telah dibangun, dimana gedung tersebut mengarah kepada pemandangan gunung salak yang bisa menjadi borrowing landscape view. Gedung sekolah Islam Terpadu Sholahuddin berwarna biru. Warna biru merupakan potensi karena warna ini merupakan warna kesukaan bagi anak usia tujuh sampai sebelas tahun (Terwogt \& Hoeksma, 2001) dan memberi pengaruh menenangkan pada detak jantung dan sistem pernafasan (Engelbrecht, 2003).

3.2.8 Fasilitas dan Utilitas

Gedung sekolah Islam terpadu sholahuddin yang masih dalam tahap pembangunan belum memiliki beberapa fasilitas dan utilitas seperti sekolah pada umumnya. Fasilitas yang tersedia pada tapak antara lain area parkir, welcome area, gedung sekolah, lapangan olahraga, serta fasilitas seperti tempat sampah, toilet, dan vegetasi. Fasilitas lainnya akan tersedia begitu pengadaan gedung sekolah sisanya telah selesai. Pada bagian selatan kawasan sekolah, akan dibangun lagi gedung sekolah selanjutnya yang terlihat sebagai area berwarna putih pada peta analisis. Kawasan tersebut tidak diperbolehkan diadakannya pengembangan lanskap pada permukaan tanahnya, tetapi nantinya akan diadakan lapangan olahraga di atas lantai dua gedung tersebut.

3.2.9 Sosial

Siswa sekolah Islam Terpadu Sholahuddin terdiri dari siswa kelas 1 sebanyak enam puluh orang, kemudian siswa kelas 2 sebanyak lima puluh delapan orang, dan staf sekolah sebanyak 20 orang. Kegiatan belajar mengajar diadakan setiap hari senin sampai dengan sabtu, dari pukul 7 pagi hingga pukul 3 sore. Istirahat diadakan setiap pukul 09.30 pagi. Aktivitas siswa sebagian besar di dalam ruangan, sedangkan kegiatan siswa di luar ruangan yaitu hanya pada saat mata pelajaran olahraga, kegiatan pelaksanaan upacara, dan waktu istirahat.

\subsection{Sintesis}

Hasil dari kegiatan analisis menunjukkan permasalahan utama pada tapak Sekolah Islam Terpadu Sholahuddin di antaranya adalah letaknya yang berada di kawasan padat penduduk dan salah satu titik kemacetan lalu lintas di Kota Bogor, luas lahan yang terbilang kecil sehingga membatasi ruang beraktivitas siswa, dan kurangnya jumlah ruang terbuka hijau di kawasan sekolah. Sintesis adalah tahap pengembangan desain dalam tapak meliputi penerapan bentukan-bentukan dalam konsep dasar dan konsep desain taman edukasi menjadi bermanfaat bagi siswa, melengkapi fasilitas serta utilitas pada tapak, memfokuskan fungsi ruang terbuka sebagai taman sekolah, tempat aktivitas outdoor siswa, sarana penunjang kegiatan belajar, sekaligus sebagai area rekreasi pasif bagi siswa. 


\subsection{Konsep}

\subsubsection{Konsep Dasar}

Konsep yang akan diaplikasikan pada Taman Edukasi di Sekolah Dasar Sholahuddin adalah filosofi dari surah Al Kausar. Kausar dalam bahasa Arab memiliki arti sebagai suatu kondisi yang berkelimpahan, biasanya terkait dengan harta \& nikmat dari Allah SWT. Kausar juga memiliki makna lain sebagai nama sungai di surga. Diinterpretasikan dari hadis Al Bukhari bahwa sungai Kausar merupakan sungai tempat berkumpulnya hamba Allah SWT dan pengikut Nabi Muhammad SAW. Sedangkan dalam hadist Muslim shahih no. 607, diriwayatkan bahwa Rasulullah SAW bersabda:

"Al kausar adalah sungai yang Allah janjikan kepadaku dimana terdapat banyak kebaikan di dalamnya. Dan nanti alirannya akan didatangi oleh umatku pada hari kebangkitan."

Taman edukasi mengangkat konsep ini untuk menciptakan lingkungan yang dapat mengakomodasi aktivitas pelajar dan menyediakan area rekreasi pasif dimana siswa dapat berinteraksi baik secara langsung maupun tidak langsung dengan tanaman, sehingga desain taman ini mampu menjadi tempat berkumpul bagi siswa sekolah.

\subsubsection{Konsep Desain}

Konsep desain yang digunakan terinspirasi dari modifikasi bentuk sungai surga Kausar yang digambarkan dalam kitab Al Quran. Konsep desain mengalami penyesuaian bentuk dengan keadaan alam di tapak, serta dengan mengacu pada ketersediaan fasilitas penunjang yang harus terdapat pada suatu sekolah dan bentukan sekolah yang sesuai dengan standar yang berlaku. Gambaran sungai di surga sebagaimana digambarkan dalam Al Quran Surat Muhammad ayat 15 (Q.S. 47:15) yang berbunyi:

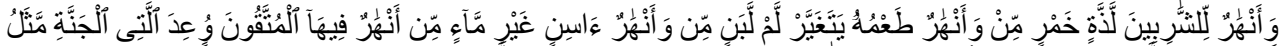

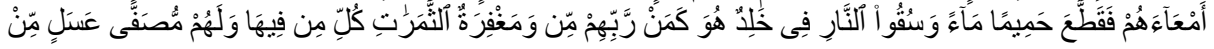

Artinya: Apakah perumpamaan (penghuni) jannah yang dijanjikan kepada orang-orang yang bertakwa yang didalamnya ada sungai-sungai dari air susu yang tidak berubah rasanya, sungai-sungai dari khamar(anggur) yang lezat rasanya bagi peminumnya dan sungai-sungai dari madu yang disaring; dan mereka memperoleh di dalamnya segala macam buah-buahan dan ampunan dari Rabb mereka, sama dengan orang yang kekal dari jahannam dan diberi minuman dengan air yang mendidih sehingga memotong ususnya.

Ayat tersebut mengatakan di lanskap surga mengalir sungai dari air, madu, susu, dan anggur. Warna dari sungai-sungai tersebut disederhanakan menjadi warna biru, putih, kuning, dan merah. Pemilihan warna berdasarkan penyederhanaan warna sungai yang digambarkan pada lanskap surga berdasarkan Al Quran akan dijadikan acuan pada tapak dalam pemilihan warna tanaman shrub sebagai tanaman estetik di sekolah. Taman islam yang mengadopsi ayat Al Quran menggunakan elemen air. Elemen air diaplikasikan sebagai warna dominan pada kawasan yaitu warna biru, sehingga memberi kesan nyaman pada penggunanya. Pada lapangan, air tidak diaplikasikan secara langsung, melainkan melalui modifikasi bentuk pavement menyerupai bentuk gelombang air yang simetris, mengacu pada konsep taman Islam yang menggunakan bentukan simetris.

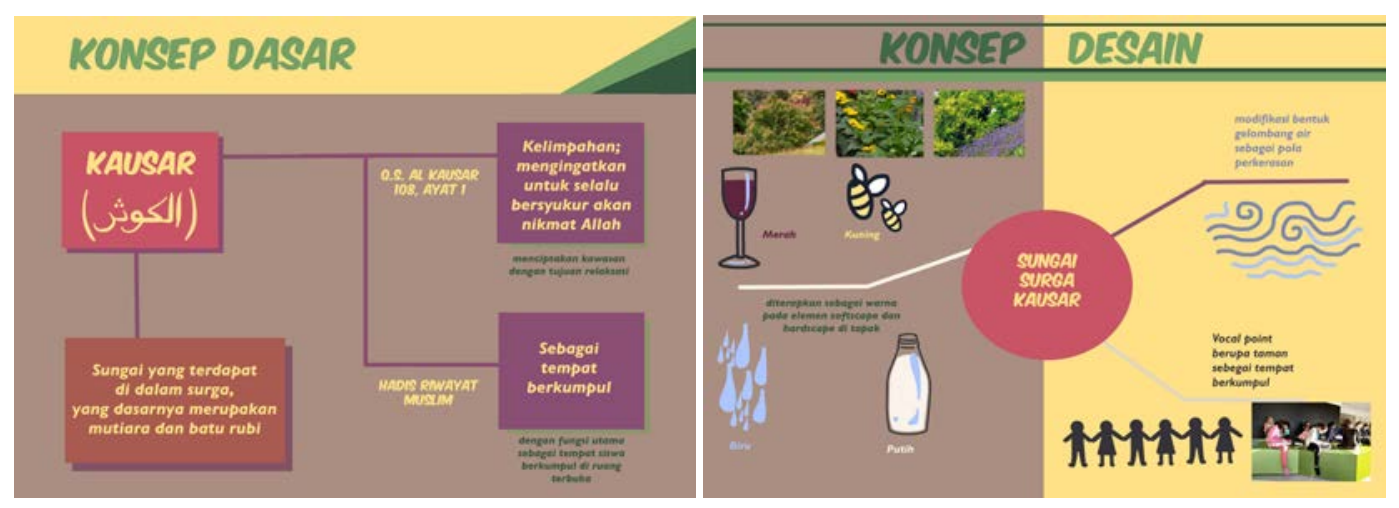

Gambar 3 dan 4 konsep dasar dan konsep desain 


\subsubsection{Konsep Pengembangan}

3.4.3.1 Konsep Sirkulasi

Konsep sirkulasi pada Sekolah Islam terpadu Sholahuddin meliputi sirkulasi primer dan sirkulasi sekunder. Sirkulasi primer adalah sirkulasi utama untuk kendaraan yang masuk menuju ke dalam tapak. Sirkulasi Sekunder adalah sirkulasi untuk pejalan kaki. Sirkulasi pada tapak dibuat bebas keluar masuk bagi pengguna. Sirkulasi di dalam sekolah dibatasi hanya untuk keperluan pejalan kaki.

\subsubsection{Konsep Ruang}

Konsep ruang dibagi berdasarkan posisi dan kegunaan. Ruang depan dijadikan lahan parkir dan welcome area. Ruang tengah akan dijadikan lapangan upacara sekaligus olahraga. Kemudian lahan di sampingnya sebagai pusat area rekreasi pasif sekaligus taman edukasi sekolah.

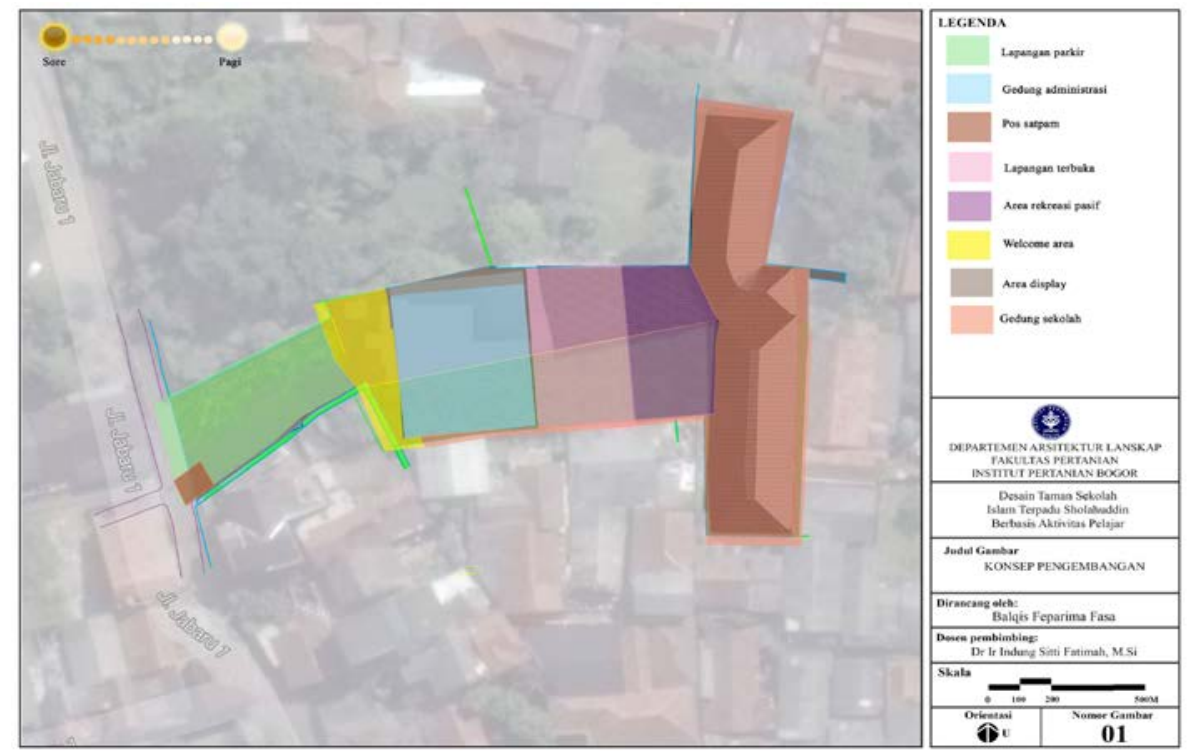

Gambar 5 Konsep ruang

\subsubsection{Konsep Vegetasi}

Konsep vegetasi yang akan digunakan terdiri dari beberapa fungsi antara lain tanaman display, tanaman pengarah, tanaman peneduh, tanaman edukasi, ground cover. Tanaman display akan diletakkan di area depan sekolah untuk menambah nilai estetik bagi lingkungan sekolah. Tanaman pengarah akan digunakan terutama pada area parkir depan sekolah, berdekatan dengan tanaman display. Ground cover digunakan untuk mengisi planter bed yang berada di dalam lingkungan sekolah untuk memberi warna hijau di dalam lingkungan sekolah. Tanaman peneduh dan tanaman edukasi akan digunakan di area rekreasi pasif. llustrasi konsep vegetasi dapat dilihat pada gambar 6 . 


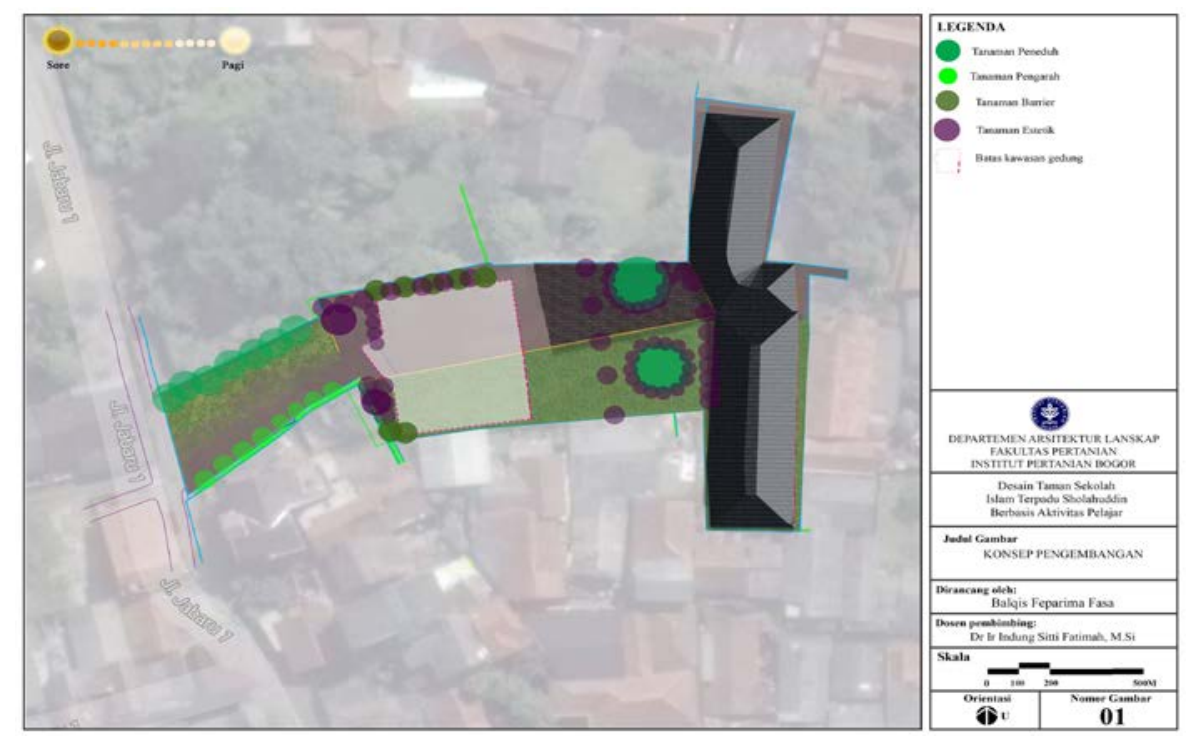

Gambar 6 Konsep vegetasi

\subsection{Desain Lanskap}

Desain Taman Edukasi Sekolah Islam Terpadu Sholahuddin adalah hasil integrasi antara konsep dasar dengan konsep desain berupa penataan untuk kawasan Sekolah Islam Terpadu Sholahuddin. Konsep desain yang digunakan adalah modifikasi sungai yang digambarkan oleh kitab Al Quran, yang digunakan adalah bentukan desain organik yang menyerupai lingkaran air. Desain Taman Edukasi di lingkungan Sekolah Dasar Islam Terpadu Sholahuddin ini memiliki tujuan untuk mampu memberi kesan nyaman dan manfaat dalam aspek edukasi bagi siswa, di samping meningkatkan kualitas estetik dari lanskap sekolah. Aspek manfaat dari taman edukasi ini yaitu untuk mampu memberi pengaruh baik bagi kondisi siswa sehingga meningkatkan performa akademik.

Desain Taman Edukasi sekolah ini meliputi bagian welcome area di depan sekolah, lahan kosong di tengah kawasan sekolah, dan gedung administrasi utama di bagian depan sekolah. Area yang didesain memiliki kesinambungan dari segi bentukan, warna, dan pembagian ruang. Bagian depan sekolah akan dibuat gerbang utama yang bentukannya serasi dengan gedung yang telah dibangun. Desain tapak akan dominan menggunakan warna-warna biru, merah, kuning, putih, dan hijau, sesuai dengan konsep desain yang dipilih. Bagian utama dari desain taman edukasi terletak pada area rekreasi pasif yang terletak di tengah kawasan sekolah, dengan penerapan warna, fungsi, dan tanaman yang sesuai.

Welcome area terletak di bagian depan kawasan sekolah. Area ini memiliki lahan parkir dan terdiri atas elemen tanaman yang bersifat ornamental sehingga memberikan kesan megah pada kawasan sekolah dan meningkatkan nilai estetik. Gedung utama dan gerbang sekolah telah didesain dengan pembingkaian sehingga menciptakan view yang menarik pada bagian depan kawasan sekolah. Di bagian tengah tapak setelah welcome area, terdapat gedung utama yang telah didesain sesuai dengan kebutuhan kegiatan pembelajaran di sekolah. Gedung utama memiliki fasilitas ruang kepala sekolah, ruang guru, kantin, perpustakaan, dan gudang peralatan.

Kawasan hijau utama pada kawasan Sekolah Islam Terpadu Sholahuddin terletak di tengah kawasan sekolah dan merupakan poin utama dari desain. Terdapat lapangan terbuka yang memiliki fungsi sebagai lapangan olahraga dan lapangan upacara. Kawasan hijau utama terdiri atas ruang terbuka dengan beragam vegetasi seperti tanaman ground cover, tanaman bunga dengan beragam warna, dan pohon peneduh. Kawasan ini juga memiliki sitting area yang dapat digunakan oleh siswa. Sitting area terletak di tengah kawasan sehingga dapat membuat siswa berinteraksi secara langsung dengan lingkungan alami pada kawasan sekolah.

Rak tanaman edukasi terletak di sepanjang bagian depan gedung kelas. Rak ini bertujuan untuk meningkatkan kualitas estetik lingkungan dengan memblok view pada kawasan padat penduduk di sekitar sekolah. Kegiatan penanaman yang bertujuan aktif bagi siswa untuk dapat berinteraksi langsung dengan lingkungan alami telah diintegrasikan dengan kegiatan non-akademik yang diadakan setiap hari jumat setelah jam belajar selesai. 


\section{Simpulan}

Visual yang baik bagi kawasan sekolah adalah lokasi yang memiliki pemandangan yang menyenangkan, area berpohon, atau setidaknya teridiri dari beberapa pohon dewasa, kawasan bebatuan, dan fitur lanskap yang menarik lainnya. Permasalahan pada Sekolah Dasar Islam Terpadu Sholahuddin merupakan sekolah yang terletak di kawasan perkotaan. Hal ini memberi manfaat baik pada sisi kemudahan dalam menjangkau kawasan sekolah, namun karena berdekatan dengan jalan sibuk dikhawatirkan dapat menimbulkan dampak negatif pada performa akademi siswa. Konsep desain taman ini menghasilkan pemilihan vegetasi dengan warna yang mampu memberi pengaruh baik bagi konsentrasi dan mood siswa, desain rekreasi pasif yang menyediakan ruang bagi siswa untuk berinteraksi dengan tanaman baik secara langsung maupun tidak langsung, dan melengkapi fasilitas penunjang kegiatan pembelajaran pada kawasan sekolah yang belum tersedia sebelumnya.

\section{Daftar Pustaka}

Chawla, L. 2001. Growing Up in an Urbanizing World. London: Routledge.

Connell, Betty Rose. et.al. 1997. The Principles of Universal Design Version. North Carolina: The Center for Universal Design North Carolina State University.

Engelbrecht, K. 2003. The impact of color on learning. NCEF Archives.

Faber Taylor, A., Kuo, F.E. \& Sullivan, W.C. 2002. Views of Nature and Self-Discipline: Evidence from Inner City Children, Journal of Environmental Psychology, 22, 49-63.

Matsuoka, Rodney H. 2010. Student performance and High School Landscapes: Examining the Links.

Sasaki, Hideo. 1950. 'Design Process', dalam Theory in Landscape Architecture. Philadelphia: University of Pennsylvania Press.

Swaffield, Simon. Theory in Landscape Architecture. 2002. Philadelphia: University of pennsylivania press.

Terwogt, M.M. \& Hoeksma, J.B. 2001. Colors and emotions: preferences and combinations. The Journal of General Psychology, 122(1), 5-17.

Venkatesha, Akshatha. 2014. High School Landscapes, halaman ii.

Widiastuti, Hartati. 2013. Peran Guru Dalam Membentuk Siswa Berkarakter. Surakarta: Universitas Muhammadiyah Surakarta. 